\title{
Ultra-low loading of platinum in proton exchange membrane-based fuel cells: a brief review
}

\author{
Aristatil Ganesan $^{1}\left[\right.$ Mani Narayanasamy ${ }^{1}$
}

Received: 7 June 2019 / Accepted: 27 August 2019 / Published online: 6 September 2019

(c) The Author(s) 2019

\begin{abstract}
This review report summarizes different synthesis methods of PEM-based fuel cell catalysts with a focus on ultra-low loading of Pt catalysts. It also demonstrates fuel cell performances with ultra-low loading of Pt catalysts which have been reported so far, and suggests a combination method of synthesis for an efficient fuel cell performance at a low loading of Pt catalyst. Here, maximum mass-specific power density (MSPD) values are calculated from various reported performance values and are discussed, and compared with the Department of Energy (DOE) 2020 target values.
\end{abstract}

Keywords Fuel cell $\cdot$ Ultra-low loading $\cdot$ MSPD values

\section{Introduction}

The fuel cell is recognized as a noble product of the twentyfirst century, as it has high potential to replace batteries, IC engines, and power grids by the virtues of efficiency and durability. Now, a great challenge is ahead to reduce the cost of fuel cells to make them available as normal commodities. Proton exchange membrane fuel cells (PEMFCs) will be a part of the modern power technology in the future. It is noted that PEMFCs have already been in the commercial market for widespread applications including automobiles, stationary power, portable power pack, and logistics [1-3].

As leading automobile manufacturers have started sales of fuel cell electric vehicles (FCEV), fuel cells are penetrating the commercial market with exponential growth. Increased sales at decreased cost are a sale economy and to achieve this, the cost of every component of the PEMFC should be considered (Fig. 1).

Regrettably, expensive platinum group metal (PGM) catalysts block the commercial sales/volume. PGMs (plus application) cost contribute to the total cost of FC stack from $21 \%$ (1000 FC systems/year) to 45\% (500,000 systems/ year) [5] as expected. Since PGMs are expensive, the PGMs loading should be reduced from current (target) levels. As

Aristatil Ganesan

arisamutha@gmail.com

$1 \quad$ Ingsman Energy and Fuel Cell Research Organization Private Limited, Chennai 600096, India
PGMs play a critical role in both hydrogen oxidation reaction (anode-HOR) and oxygen reduction reaction (cathode-ORR) of the fuel cell, the challenge is ahead in the PEMFC community to address PGM cost issues for its use in both anode and cathode of the fuel cell.

Since PEMFCs will be in the automotive market, this drives long-term cost analysis and catalyst requirements. Nevertheless, the market spaces for PEMFCs are being extended to portable power, backup power, materials handling, stationary power pack, and buses. In addition to huge market availability for PEMFC automotives, there is another market available for PEMFCs, as mentioned above. Catalyst developers are encouraged to keep in mind the above discussion, to focus and develop next-generation catalysts which have huge commercial opportunities. According to DOE 2020, the loading target of PGM is $0.0250 .025 \mathrm{mgcm}^{-2}$ and $<0.1 \mathrm{mgcm}^{-2}$ for the anode and cathode, respectively. Nevertheless, a still lower loading of about $0.0625 \mathrm{mgcm}^{-2}$ is required for PEMFC vehicles to stand along with IC engine vehicles [6].

\section{Literature}

Many research groups are working on Pt alloy catalysts such as PtCo; PtNi; PtCoMn; WSnMo; PtRu; PtAgRu; PtAuRu; PtRhRu; and Pt-Ru-W2C to replace Pt/C [7-10]. By providing high surface area carbon supports, $\mathrm{Pt}$ content could be reduced with high Pt utilization [11, 12]. Using 


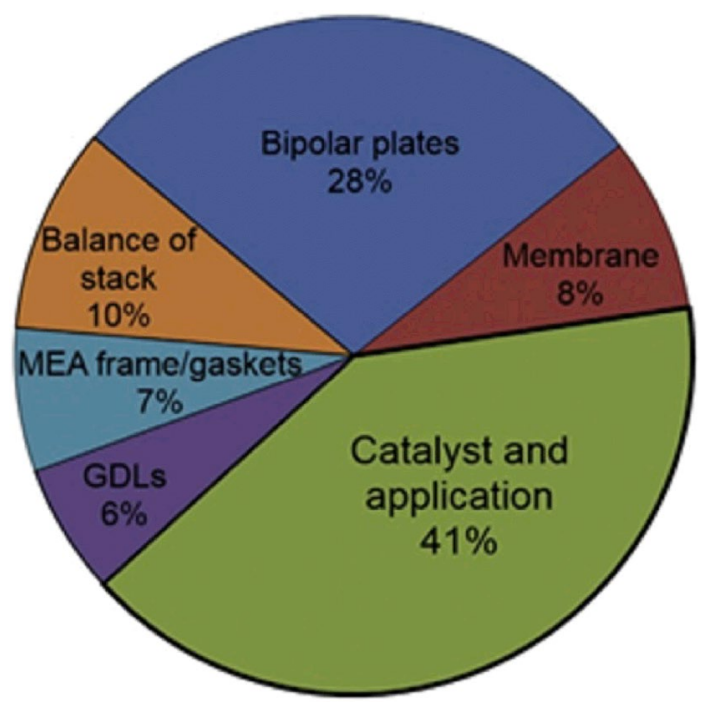

Fig. 1 Component cost breakdown at a production volume of 500,000 units/yr for the FC stack [4]

the plasma sputtering technique [13], the total Pt loading in both anode and cathode is reduced to $20 \mu \mathrm{gcm}^{-2}$. By this method, uniform dispersion of $\mathrm{Pt}$ as clusters with size less than $2 \mathrm{~nm}$ is achieved with high catalyst utilization.

Most researchers have made an attempt to reduce $\mathrm{Pt}$ loading by providing novel catalyst supports such as multiwalled CNT and single-walled CNT [14]. Binary alloys of Pt, Pt-Cu [15], Pt-Co [16-19], Pt-Ni [17, 18], Pt-Cr [17] revealed 2-3 times higher mass-specific activity than $\mathrm{Pt} / \mathrm{C}$, which is due to alloy effects and ligand effects. A ternary alloy of PtFeNi and PtFeCo [19] showed excellent ORR activity, but in some cases presents Pt particles aggregation. A bimetallic alloy of $\mathrm{Pd}-\mathrm{Pt}$ on hollow core mesoporous shell carbon (PtPd/HCMSC) demonstrated enhanced ORR activity and stability [20,21]. Recently, a core shell of PtCo@Pt offered low loading of catalyst, but it had a disadvantage of base metal cobalt (Co) leaching (dissolution) from bulk to surface [22]. Wang et al. [21] investigated PtNi alloy as a high-performing catalyst for automotive applications with a low loading of $\mathrm{Pt}$ : $0.125 \mathrm{mgcm}^{-2}$ which satisfied the DOE 2020 target.

Pt-Ni alloy catalyst synthesized by direct current magnetron sputtering involves Pt sputtering on synthesized $\mathrm{PtNi} / \mathrm{C}$ substrate which forms multilayered Pt-skin surface, with superior ORR activity. This catalyst involves the mature technology of synthesis with improved performance compared to Pt/C. Though this catalyst presents superior performance, it involves careful preparation of Pt target material for sputtering (costly), preparation of PtNi by chemical reduction, thermal decomposition, and acid treatment with final heat treatment. Materials' preparation involves many steps and needs careful optimization for getting a reasonable yield of catalyst. Durability studies were not conducted at the MEA level as it is specified by DOE.

Kongkanand et al. investigated [22] PtCo on high surface area carbon (HSC), which demonstrates a less degree of PtCo particle coalescence after the stability test. Also, HSC is favored for start-up performance and long-term durability. The dissolution of $\mathrm{Pt}$ and Co was resolved by developing a deposition model [23]. DOE has updated its cost estimation for an automotive fuel cell by $15 \%$, i.e., $\$ 45 /$ $\mathrm{kW}$, because of the development of catalyst, $\mathrm{PtCo} / \mathrm{HSC}$. This catalyst system would reduce the total cost of the system to $14 \%$ or $\$ 7.5 / \mathrm{kW}$ [22]. These catalysts $(\mathrm{PtNi} / \mathrm{PtCo})$ cost about $\$ 15.20 / \mathrm{g}$ for cathode $\left(\mathrm{Pt} 0.100 \mathrm{mgcm}^{-2}\right.$ ) and $\$ 10.86 / \mathrm{g}$ for Anode (Pt $0.025 \mathrm{mgcm}^{-2}$ ) [1]. Chen et al. investigated $\mathrm{Pt}_{3} \mathrm{Ni}$ nanoframes and demonstrated high mass activity with durability, but MEA performance at high current density was challenging [23]. The shape-controlled synthesis of Pt-Pd and $\mathrm{Ru}-\mathrm{Rh}$ catalyst showed high mass activity and it offers a commercially efficient scale-up method. This catalyst has issues with performance at the MEA level and stability [24]. In addition to catalyst support modification, and alloying of $\mathrm{Pt}$, for $\mathrm{Pt}$ content reduction, a proper MEA fabrication methodology is to be identified for low Pt loading. This review provides intensive guidance for researchers working on low Pt loading catalyst for fuel cells.

\section{Most promising methods for the preparation of electrodes}

Though there are several methods such as physical vapor deposition, chemical vapor deposition, sputter deposition, galvanic replacement reaction (Pd nanocrystals with different shapes) [24] hydrothermal synthesis [25] electrodeposition (hetero-structured nanotube dual catalyst) [26] electrospinning [27] and molten salt method [28], electrodeposition [29] are available for catalyst synthesis and coating, only very few methods are practically feasible for producing nanoparticles of a catalyst and its efficacy for coating on electrodes.

\section{Electrodeposition}

The need and necessity for nanostructured energy materials with high surface area, and for its efficient application in energy conversion devices, can be achieved only with the electrochemical synthesis route. Electrodeposition technique proves to be the best method for the following reasons [30, 31].

1. Electrode potential, deposition potentials, current densities, and bath concentrations could be controlled for the synthesis of homogenous nanostructured materials. 
Hence by varying deposition parameters, one can synthesize thin catalyst film, with desired stoichiometry, thickness, and microstructure.

2. Particle size, desired surface morphology, catalyst loading, thickness, and microstructure can be easily achieved using various control parameters involved in electroplating.

3. Electrochemical reactions proceeded at ambient temperature and pressure, as high thermodynamic efficiency during plating is maintained.

4. Environmentally friendly.

5. Synthesis can be started with low-cost chemicals as precursor materials.

6. One-pot single-step synthesis of the final product is possible by avoiding a number of steps.

7. Any metal or alloy can be easily doped into desired nanostructured materials.

8. The required nanostructured energy materials can be directly grown on the electrode surface by electrochemical method, and it provides good adhesion, large surface area, and electrical conductivity. And hence, this method is found suitable for construction of energy devices with high efficiency and with low cost.

9. By this method, materials with poor electrical conductivity of metal oxide used as catalyst supports can be easily incorporated into advanced energy materials and will facilitate fast electron transport mechanism. Therefore, electrical conductivity of catalyst supports can be enhanced by the electrodeposition method.

10. The electrochemical synthesis route eliminates the complexity of mixing catalyst powders with carbon black and polymer binder in fabricating electrodes for fuel cells in a short time [29].

\section{Experiment: [29]}

There are two modes of electrodeposition, viz, pulse and direct current (DC) deposition. Pulse deposition results in a high concentration of metal ions at the vicinity of the electrode surface, during ON time, and no coating during OFF time, this creates homogenous mixing of electrolyte and uniform coating with different surface morphologies [32] on the working electrode. Also, it offers efficient mass transfer kinetics by varying pulse parameters, ON time, OFF time, and peak current density. In each pulse, there is a periodic switching of current between ON time and OFF time (no current) when plating occurs. A typical pulse diagram is as shown in Fig. 2 [33].

The basic pulse mathematics needs to be known for understanding the terms involved in the pulse cycle. In a pulsed current deposition, duty cycle $(\gamma)$ is the total time of a cycle in percentage [34], and its reciprocal is frequency $(1 / T)$.

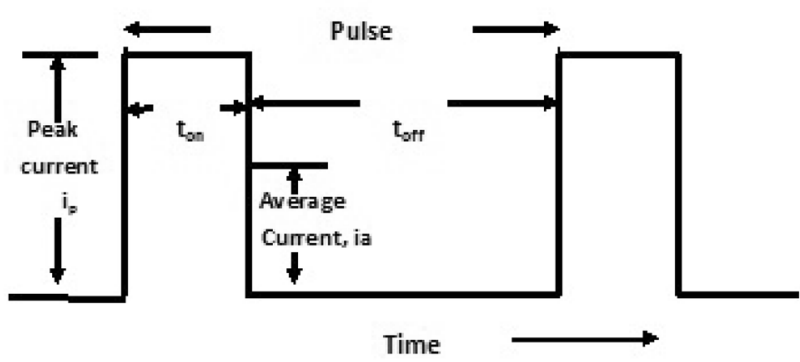

Fig. 2 Typical waveform of a pulse deposition mode of electroplating

$$
\begin{aligned}
\text { Duty cycle } & =\frac{T_{\text {on }}}{T_{\text {on }}+T_{\text {off }}}=T_{\text {on }} \times f \text { or Frequency }(f) \\
& =\frac{1}{T_{\text {on }}+T_{\text {off }}}=\frac{1}{T}
\end{aligned}
$$

The average current density $\left(I_{\mathrm{A}}\right)$ is defined as:

$I_{\mathrm{A}}=$ Peak current $\left(I_{\mathrm{p}}\right) \times$ Duty cycle $(\gamma)$

In DC deposition, the formation of negative charge cloud around the cathode would hinder the movement of ions, but in the case of pulse electrodeposition (PED), the charge cloud will get discharged and permits metal ions to migrate to form a coating on working electrode. In the electrolyte bath solution, there is a scarcity of metal ions in peak current density areas when compared to low current density regions. In PED, during $T_{\text {off }}$, metal ions migrated into regions where there is a lack of metal ions in bath. During $T_{\text {on }}$, the metal ions are readily available for plating on the electrode. Peak current $\left(I_{\mathrm{p}}\right)$ will increase the density of adatoms and nucleation rate during $T_{\text {on }}$ and form fine-grained microstructure. The distortions during $T_{\text {off }}$ may result in re-nucleation, which is due to the removal of impurities. At low duty cycle, higher $I_{\mathrm{p}}$ is required for medium deposition rate, and the duty cycle is to be maintained as a minimal range $33-50 \%$. During $T_{\text {on }}$, there is a lack of uniformity of current distribution at higher $I_{\mathrm{p}}$, irrespective of waveform employed during plating, and $T_{\text {off }}$ time influences additives' mass transfer in the electrolyte. For plating of alloys, usually, high-frequency pulses are preferred for homogenous coating and desired composition. By manipulating $T_{\text {on }}$ and $T_{\text {off }}$, the composition of alloy can be modified by producing multilayered deposits [25].

\section{Chemical precipitation method [35]}

A thin nanocatalyst layer is formed by the reduction of reducing agent in the precursor solution. The desired particle size of the catalyst can be achieved by varying parameters, such as temperature, $\mathrm{pH}$, the ratio of reducing ion to $\mathrm{Pt}$, 
reaction time, and stirring rate. The main disadvantage of this method is producing irregular particle size and shape, and resulting in the inhomogeneous layer. This formation is due to various growth kinetics and conditions, and thus it is least used for catalyst synthesis.

\section{Colloidal method [36]}

By this method, colloidal dispersion is formed by stabilizer and the precursor. The suitable support material is added and by which colloid deposition occurs on the support surface. In the final stage, the decomposition of colloid results in the formation of catalyst. The common colloidal particles formed by the precursors, $\mathrm{H}_{2} \mathrm{PtCl}_{6}$ and $\mathrm{RuCl}_{3}$, and reduced with reducing agent. The stabilizers and reducing agents present in the final product will have to be removed by thermal treatment. This method involves various steps to be followed for the catalyst synthesis.

\section{Sol-gel synthesis method [37]}

This method allows forming solid particles suspended in liquid solution (sol) and upon subsequent aging, and drying to form a semi-solid suspension in a liquid (gel). And subsequent calcination results in a mesoporous solid or powder formed on the substrate. Pore size distribution on the catalyst layer can be varied by various experimental parameters. The disadvantage associated with this technique is catalytic burning in pores, makes them inaccessible to reactants, and resulting in low catalyst utilization.

\section{Impregnation method [38]}

This method uses high surface area carbon supports for the formation of catalyst. In this method, chloride Pt salt directly mixed with reducing agents, $\mathrm{Na}_{2} \mathrm{~S}_{2} \mathrm{O}_{3}, \mathrm{NaBH}_{4}, \mathrm{~N}_{2} \mathrm{H}_{4}$, formic acid, and $\mathrm{H}_{2}$ gas in an aqueous solvent. This method results in Pt agglomeration and weak support due to the high surface tension of the liquid solution [56].

\section{Microemulsion method [39]}

The water-soluble inorganic salt was used as a metal precursor in the solution. Here the particle growth rate, size, and shape are being decided by a proper proportion of metal salt and organic solvent and the resulting solution forms water-in-oil structure (microemulsion). The hydrophobic property of organic molecules protects the metal particle as an insulation layer and prevents agglomeration when the reducing agent is added. That is a surfactant-assisted synthesis of catalyst which forms suitable catalyst support with the protection layer. The main drawback of this method is the use of expensive chemicals and not being environmentally friendly [39].

\section{Microwave-assisted polyol method [40] [41]}

Here, Pt metal salts are reduced in ethylene glycol, and the reduction reaction occurs at a temperature above $120{ }^{\circ} \mathrm{C}$. Microwave-assisted heating could produce more active ORR catalyst than the conventional heat treatment. Microwave heating produces uniform dispersion and greater morphological control over particle size $(<3 \mathrm{~nm})$. The main advantage of this method is that it has no surfactant addition and uses an inexpensive solvent like ethylene glycol. The disadvantage associated with this method is that it is time consuming.

\section{Chemical vapor deposition (CVD) [42]}

This method uses the required precursors in the gas phase using external heat energy plasma sources in an enclosed media-assisted chamber. The thin solid film formed on the substrate by decomposition reaction of precursors. The impurities produced during reaction is removed by the flowing media gas into the chamber. This method is most widely used for the synthesis of advanced materials like CNT and graphene. This method involves a huge cost for instruments and process.

\section{Spray technique [43]}

Spray painting involves printing techniques for coating catalyst directly on the substrate, and it involves inkjet printing, casting, sonic method, etc. The advantage of printing technique is that we can coat a large area of the electrode, irrespective of surface (conductive or non-conductive) of the substrate. After coating, the coated surface is allowed for evaporation of the solvent. Though many advantages are provided by this technique, it has a large influence on practical applicability and mass production, so catalyst utilization is very low.

\section{Atomic layer deposition (ALD) [44]}

This method is under the sub class of CVD. Here gas phase molecules are used sequentially to deposit atoms on the substrate. The precursors involved react on surface one at a time, in sequential order. The substrate is exposed to different exposures at different time and forms uniform nanocoating on the substrate. This method involves four steps to complete the whole process: (1) exposure to precursor first, (2) purging of the reaction chamber, (3) exposure to second reactant precursor, and (4) a further purge of the reaction chamber. During step 1 and 2, the precursors react with the substrate at all available reactive sites. The unused precursors 
and impurities are removed by purging the inert gas. During the third stage, the adsorbed precursor on the substrate starts reacting with reactant precursor to eliminate ligands of the first precursor for forming target material, while the residues formed in step 3 are eliminated in step 4 of inert gas purging which complete one cycle; likewise many cycles are repeated to achieve desired thickness of the target material.

\section{Key features to consider when preparing the electrodes}

In emerging hydrogen economy, fuel cell technology developments need to be redressed in cost effectiveness and benchmark performance as directed by DOE US and operation under long life cycles.

There are many ways to reduce the cost of fuel cells without sacrificing performance and are [45-50] listed below:

1. reduction of precious metal loading.

2. Nanostructured thin-film (NSTF) development for catalyst layer.

3. Particle size reduction for electrocatalyst.

4. Developing non-precious metal/alloy.

5. Developing novel catalyst preparation methods.

6. Using novel MEA fabrication methods to adopt for advanced catalyst and membrane materials.

7. Adopting new techniques to promote triple-phase boundaries and mitigate mass transfer limitation.

8. Attempt to develop carbonaceous and non-carbonaceous catalyst support materials to achieve peak performance at low-cost investment.

In addition to various useful applications of PEMFC, still, it has to go a long way in terms of catalyst for successful commercialization, like cost, efficiency, and cycle stability. Even now, Pt/Pt-based materials hold its strong position in functioning as an efficient catalyst for PEMFC and DMFC, as it exhibits superior catalytic activity, electrochemical stability, high exchange current density, and excellent work function [50-53].

Due to the lack of Pt resources in earth's crust, they are a costlier and limited supply for industries. In regard to PEMFC automotive applications, the present resources of Pt are not sufficient to fulfill the requirements, and the obtained ORR activity is also not up to the benchmark performance [51]. Because of these reasons, researchers are now focussed mainly on synthesizing ultra-fine nanoparticles of $\mathrm{Pt}$, alloying with other metals, and ultra-low loading of Pt on highly porous, high surface area metal oxide/composite support to reduce the cost without sacrificing the performance [52]. Usually, conductive porous membranes are used as catalyst support materials for PEMFC and DMFC, but the use of metal catalyst support shows higher stability, and activity when compared to unsupported catalyst.
The typical characteristics of catalyst support are as follows:

High surface area.

Ability to maximize triple-phase boundary through their mesoporous structure.

Good metal-catalyst support interaction.

High electrical conductivity.

Good water management.

Increased resistance to corrosion.

Ease of catalyst recovery [54].

Support material, in addition to increasing catalytic activity and durability, also determines the particle size of a metal catalyst. Hence, the choice of support material should be chosen, in such a way that it supports performance, behavior, long cycles of operation, and cheaper cost of catalyst.

The following steps should be considered for developing a new catalyst system,

- Developing non-precious metal catalyst.

- Choice of suitable catalyst support materials.

The metals other than Pt group are palladium, ruthenium, rhodium, iridium, and osmium. The availability of these metals is scarce compared to Pt. Hence by incorporating all the above points and alloying with non-Pt group metals, the loading of precious metal could be reduced with higher performance [55]. The essential properties of support materials discussed above are important to achieve better performance of fuel cell at a cheaper cost.

\section{Stability}

The major issue with PEMFC catalyst is long-term durability. During the continuous operation of PEMFC, catalytic agglomeration, and electrochemical corrosion of carbon-based support result in deterioration of catalyst activity [53]. By choosing the correct catalyst support, one can eliminate the agglomeration of catalyst, and corrosion of support. With the existing carbon black support, the electrochemical corrosion triggers at above $0.9 \mathrm{~V}$ which results in the catalyst getting detached from support, and agglomerates. It will create a lack of diffusion of fuel/ oxidant reactants and reduces overall fuel cell performance, and life. These issues force us to find a solution for long cyclic stability of PEMFC by choosing proper support, which has strong electrochemical stability under acid/alkaline medium.

The most widely used support materials are carbon black with various grades from various companies based on quality in terms of porosity and surface area. Since from last decade, the researcher's focus is on nanostructured catalyst supports, as they deliver faster charge transfer, surface area, 
Table 1 Summary of different synthesis methods as discussed in "Most promising methods for the preparation of electrodes" to "Atomic layer deposition (ALD)"

\begin{tabular}{|c|c|c|c|}
\hline Synthesis methods & Advantages & Disadvantages & Commercial viability \\
\hline Electrodeposition & $\begin{array}{l}\text { One step method, short time required, } \\
\text { avoid complicated synthesis methods, } \\
\text { high purity and particle size, less } \\
\text { fatigue and cheap fabrication method }\end{array}$ & External power supply is required & Good \\
\hline Chemical precipitation method & Involves no bigger instruments or devices & $\begin{array}{l}\text { Long-term process, involves careful } \\
\text { attention in preparation }\end{array}$ & Good \\
\hline Colloidal method & Involves no bigger instruments or devices & $\begin{array}{l}\text { Many more steps involved, long time } \\
\text { is required, stabilizers and reducing } \\
\text { agents have to be removed }\end{array}$ & Moderate \\
\hline Sol-gel synthesis method & $\begin{array}{l}\text { Wet method, involves no bigger instru- } \\
\text { ments or devices }\end{array}$ & $\begin{array}{l}\text { Less mass transfer and low utilization of } \\
\text { catalyst }\end{array}$ & Moderate \\
\hline Microemulsion method & Simple method & $\begin{array}{l}\text { Expensive chemicals and their activity is } \\
\text { not environmentally friendly }\end{array}$ & Moderate \\
\hline Microwave-assisted polyol method & Simple and most commonly used method & Takes a long time to complete a reaction & Moderate \\
\hline Chemical vapor deposition (CVD) & $\begin{array}{l}\text { More precision and accuracy, high purity } \\
\text { of materials }\end{array}$ & $\begin{array}{l}\text { Costly chemicals, expensive instruments, } \\
\text { highly operator oriented }\end{array}$ & Moderate \\
\hline Spray technique & $\begin{array}{l}\text { Easy method, direct application of nano- } \\
\text { materials, tunable to desired catalyst } \\
\text { loading }\end{array}$ & $\begin{array}{l}\text { High amount of catalyst loading, } \\
\text { time consuming, operator oriented, } \\
\text { agglomeration of particles, less catalyst } \\
\text { utilization }\end{array}$ & Moderate \\
\hline Atomic layer deposition (ALD) & $\begin{array}{l}\text { High accuracy method, more precision, } \\
\text { desired particle size or in atom level, } \\
\text { ultra-low loading of catalyst with high } \\
\text { performance of devices }\end{array}$ & $\begin{array}{l}\text { Very expensive instruments, need } \\
\text { more control over operations, costly } \\
\text { chemicals }\end{array}$ & Moderate \\
\hline
\end{tabular}

Table 2 Development criteria for automotive fuel cell electrocatalysts [51] Reproduced with permission from Publishers: Nature, Order Number: 4638121383737 Title: Electrocatalyst approaches and challenges for automotive fuel cells, Mark K. Debe

Must meet beginning-of-life performance targets at full and quarter power
Must meet end-of-life performance targets after 5000 h or 10 years operation
Must meet performance, durability and cost targets and have less than $0.125 \mathrm{mg}^{\mathrm{P}} \mathrm{PM}$ per $\mathrm{cm}^{2}$
Corrosion resistance of both Pt and the support must withstand tens of thousands of start-up/shut-down events
Must have low sensitivity to wide changes in relative humidity
Must withstand hundreds of thousands of load cycles
Must have adequate cool start, cold start and freeze tolerance
Must enable rapid break-in and conditioning (the period needed to achieve peak performance)
Must have high robustness, meaning tolerance of off-nominal conditions and extreme-load transient events
Must produce minimal $\mathrm{H}_{2} \mathrm{O}_{2}$ production from incomplete ORR
Must have high tolerance to external and internal impurities (for example, Cl2) and ability to fully recover
Must have statistically significant durability, meaning individual MEA lifetimes must enable over $99.9 \%$ of
stacks to reach 5000 -h lifetimes
Electrodes must be designed for cost-effective Pt recycling
Environmental impact of manufacturing should be minimal at hundreds of millions of square meters per year
Environmental impact must be low over the total life cycle of the MEAs
Manufacturing rates will need to approach several MEAs per second
MEA manufacturing quality must achieve over $99.9 \%$ failure-free stacks at beginning of life (one faulty MEA
in 30,000 for just $1 \%$ stack failures).
Proven high-volume manufacturing methods and infrastructure will be required
Catalyst-independent processes will be preferred, to enable easy insertion of new-generation materials

and improved catalytic activity. They are broadly classified into carbonaceous and non-carbonaceous supports.

Carbonaceous type includes different types of modified carbon materials such as mesoporous carbon, carbon nanotubes (CNTs), nanodiamonds, carbon nanofibers (CNF), and graphene [36, 54-61]. This nanostructured modified carbon offers high surface area, high electrical conductivity, and good stability in acid and alkaline environments. High crystallinity of carbon nanomaterials, such as CNT and CNF, exhibits stability and good activity [62]. 
However, under repeated cycles of fuel cell operation, carbon materials such as carbon black face serious problems of corrosion. Though there is considerable decrement of corrosion rate with higher graphitic carbon materials such as carbon nanotubes, carbon nanofibers, they do not prevent carbon oxidation [63]. To achieve high corrosion/oxidation resistant, stability, and durability; metal oxides are preferred as a good catalyst support material instead of carbon [52, 64]. Metal oxides offer [62, 64]:

high electrochemical stability,

mechanical stability,

porosity,

high surface area,

cycling stability and durability $[62,63]$.

Debe et al. derived development criteria for automotive fuel cell electrocatalysts as given in Tables 1 and 2. They proposed that increased surface area of catalyst will improve the activity of the outer Pt layer [65]. Nanostructured thinfilm (NSTF) catalysts will give high surface area for efficient

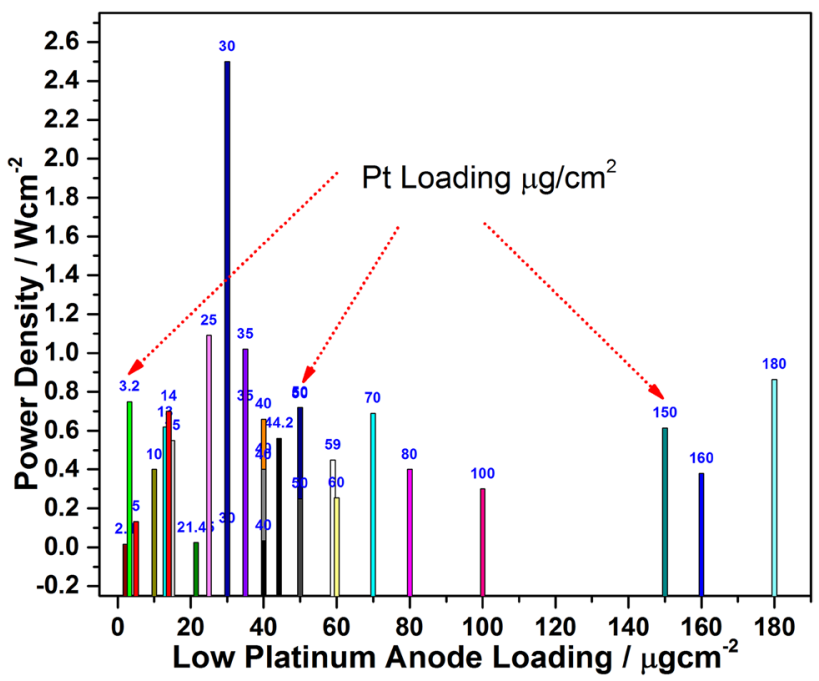

Fig. 3 Fuel cell performances with different anode catalyst loading, and comparison with literature values (as per data in Table 3)

Table 3 Ultra-low loading of anode catalyst

\begin{tabular}{|c|c|c|c|c|c|}
\hline S1. no & Anode $\mathrm{mgcm}^{-2}$ & Cathode $\mathrm{mgcm}^{-2}$ & Power $\mathrm{Wcm}^{-2}$ & Experiment conditions & References \\
\hline 1 & 0.0442 & 0.546 & 0.561 & Back pressure 1 bar (anode/cathode) & {$[74]$} \\
\hline 2 & 0.005 & 0.005 & 0.132 & $\begin{array}{l}\mathrm{H}_{2} / \mathrm{O}_{2} \\
\mathrm{No} \text { bp }\end{array}$ & {$[75]$} \\
\hline 3 & 0.04 & 0.04 & 0.43 & Back pressure 4 bar (anode/cathode) $\mathrm{H}_{2} /$ air & [76] \\
\hline 4 & 0.05 & 0.05 & 0.714 & Back pressure 2.7 bar (anode/cathode) & [77] \\
\hline 5 & 0.013 & 0.4 & 0.619 & $\mathrm{H}_{2} / \mathrm{O}_{2} \mathrm{No} \mathrm{bp}$ & {$[78]$} \\
\hline 6 & 0.08 & 0.08 & 0.4 & $\mathrm{H}_{2} / \mathrm{O}_{2} \mathrm{No} b p$ & [79] \\
\hline 7 & 0.03 & 0.03 & 0.07 & Back pressure 1.5 bar (anode/cathode) & {$[80]$} \\
\hline 8 & 0.01 & 0.01 & 0.4 & Back pressure 3.8 bar (anode/cathode) & [13] \\
\hline 9 & 0.05 & 0.1 & 0.720 & $\mathrm{H}_{2} / \mathrm{O}_{2} \mathrm{No} \mathrm{bp}$ & {$[81]$} \\
\hline 10 & 0.035 & 0.5 & 0.7 & Back pressure 1.5 bar (anode/cathode) & {$[82]$} \\
\hline 11 & $\begin{array}{l}0.0021 \\
0.02145\end{array}$ & $\begin{array}{l}0.05 \\
0.05\end{array}$ & $\begin{array}{l}0.016 \\
0.024\end{array}$ & $\mathrm{H}_{2} / \mathrm{O}_{2} \mathrm{No} b p$ & {$[83]$} \\
\hline 12 & 0.15 & 0.022 & 0.614 & Back pressure 1.72 bar (anode/cathode) & {$[84]$} \\
\hline 13 & 0.029 & 0.029 & 2.5 & Back pressure 3 bar (anode/cathode) & {$[85]$} \\
\hline 14 & 0.04 & 0.12 & 0.66 & Back pressure 3 bar (anode/cathode) & {$[86]$} \\
\hline 15 & 0.035 & 0.035 & 1.02 & Back pressure 2.06 bar (anode/cathode) & {$[87]$} \\
\hline 16 & 0.1 & 0.029 & 0.3 & $\mathrm{H}_{2} /$ air No bp & {$[88]$} \\
\hline 17 & 0.059 & 0.055 & 0.45 & $\mathrm{H}_{2} /$ air No bp & \\
\hline 18 & 0.015 & 0.04 & 0.55 & Back pressure 2 bar (anode/cathode) $\mathrm{H}_{2} /$ air & [89] \\
\hline 20 & 0.06 & 0.4 & 0.254 & $\mathrm{H}_{2} / \mathrm{O}_{2} \mathrm{No} b p$ & {$[90]$} \\
\hline 21 & 0.18 & 0.5 & 0.864 & $\mathrm{H}_{2} / \mathrm{O}_{2}$ No bp & [91] \\
\hline 22 & 0.025 & $0.1(\mathrm{PtCo})$ & 1.09 & Back pressure 2.5 bar (anode/cathode) $\mathrm{h}_{2} /$ air & {$[4]$} \\
\hline 23 & 0.05 & 0.05 & 0.25 & $\mathrm{H}_{2} / \mathrm{O}_{2} \mathrm{No} b p$ & {$[92]$} \\
\hline 24 & 0.04 & 0.04 & 0.033 & Dry $\mathrm{H}_{2} / \mathrm{O}_{2}$ No bp & {$[93]$} \\
\hline 25 & 0.014 & 0.3 & 0.7 & Back pressure 2 bar (anode/cathode) & [94] \\
\hline 26 & 0.16 & 0.16 & 0.38 & Back pressure 4 bar (anode/cathode) $\mathrm{H}_{2} /$ air & [76] \\
\hline
\end{tabular}

$B p$ back pressure 
activity for the catalyst. NSTF electrocatalysts offer areaspecific activity $[66,67]$ of the catalyst, catalyst utilization, stability $[68,69]$, and performance with ultra-low PGM loadings [70].

\section{Problems associated with ultra-low loading}

During continuous operation of fuel cell, there will be a loss in ECSA due to dissolution, agglomeration, and Ostwald ripening. So, catalyst stability and durability are being decided by ECSA loss before and after operation of specified hours. Most recent catalyst systems with ultra-low loading present very high mass activity $(30 \times$ higher mass activity vs. Pt/C), but they fail at high current density targets. For example, core-shell ( $\mathrm{Pt} @ \mathrm{Pd} / \mathrm{C})$ catalysts exhibit higher mass activity but undergo some degree of base metal dissolution [71]. So, new catalyst development with the focus on ultralow loading of precious metal and stability at high current densities (HCD) is required even though they exhibit higher mass activity.

\section{Requirements of cathode catalysts}

PGM alloy shows high performance at the beginning and offers higher ohmic/mass transport losses during continuous operation. During long cycling, a conventional Pt/C lost its performance by degradation (dissolution, agglomeration, and Ostwald ripening). And PGM alloy contaminates ionomer by the dissolution of ions and results in additional performance loss at high current densities. Hence, a novel cathode catalyst layer is required for high performance and durability. As pointed out earlier, most Pt alloy catalysts with high mass activity show high performance at low current densities, but suffer from performance loss at high current densities due to base metal or support dissolution, and it is progressive when operating under voltage cycling. Hence, a novel cathode catalyst layer design is proposed to get rid of the above-discussed problems and to deliver stable performance/durability. Dustin Banham et al. [72] presents realworld requirements for the design of PEMFC catalysts.

Table 4 Ultra-low loading of catalyst (both anode and cathode) by various synthesis methods, MSPD and peak power

\begin{tabular}{|c|c|c|c|c|}
\hline Catalyst synthesis method & Catalyst (anode/cathode) & MSPD $\mathrm{mW}_{\mu \mathrm{g}^{-1}}{ }_{\text {Pt total }}(0.65 \mathrm{~V})$ & Peak power $\mathrm{Wcm}^{-2}$ & References \\
\hline Spraying & $\mathrm{Pt}$ & 2.96 & 0.66 & {$[86]$} \\
\hline Sputter deposition & $\mathrm{Pt}$ & 9.1 & 0.132 & {$[75]$} \\
\hline Plasma sputtering technique & $\begin{array}{l}\mathrm{Pt} \\
\mathrm{Pd} @ \mathrm{Pt}\end{array}$ & $\begin{array}{l}20 \text { (peak) } \\
13 \\
1.65 \\
2.28(0.5 \mathrm{~V})\end{array}$ & $\begin{array}{l}0.4 \\
0.260\end{array}$ & {$[13,95]$} \\
\hline Electrospraying & $\begin{array}{l}\mathrm{Pt} \\
\mathrm{Pt}\end{array}$ & $\begin{array}{l}2.16(\text { peak }) \\
0.128(0.65) \\
0.04\end{array}$ & $\begin{array}{l}0.243 \\
0.150\end{array}$ & {$[96,97]$} \\
\hline Electrospinning and electrospraying & $\mathrm{Pt}$ & $\begin{array}{l}5.4 \text { (peak) } \\
3.21\end{array}$ & 1.06 & [84] \\
\hline Ultrasonic spray technique & $\mathrm{Pt}$ & 1.15 & 0.695 & [98] \\
\hline Spraying and sputtering & $\mathrm{Pt}$ & $\begin{array}{l}14.5 \text { (peak) } \\
9.28\end{array}$ & 1.02 & [87] \\
\hline Electrospinning & $\mathrm{Pt}$ & 1.30 & 0.306 & {$[88]$} \\
\hline Hand painting or modified thin film & $\mathrm{Pt}$ & 4.06 & 0.714 & {$[77]$} \\
\hline Inkjet & $\mathrm{Pt}$ & 1.95 & 0.35 & {$[80]$} \\
\hline Electrodeposition & $\begin{array}{l}\mathrm{Pd} @ \mathrm{Pt} \text { and } \mathrm{Pt} / \mathrm{C} \\
\mathrm{PtRu} \text { and } \mathrm{Pt} / \mathrm{C} \\
\text { DMFC }\end{array}$ & $\begin{array}{l}3.62(\mathrm{Pt} / \mathrm{pd} \text { as anode }) \\
3.92(\mathrm{Pt} / \mathrm{pd} \text { as cathode }) \\
0.14 \\
\text { DMFC }\end{array}$ & $\begin{array}{l}0.780 \\
0.068\end{array}$ & {$[89,99]$} \\
\hline Dual ion beam-assisted deposition & $\begin{array}{l}\mathrm{Pt} \\
\mathrm{Pt}\end{array}$ & $\begin{array}{l}3.3 \\
3.36\end{array}$ & $\begin{array}{l}0.43 @ 0.65 \mathrm{~V} \\
0.38\end{array}$ & {$[76,100]$} \\
\hline Doctor blade & $\mathrm{Pt}$ & 3.12 & 0.48 & {$[101]$} \\
\hline Piezo-electric printing & $\mathrm{Pt}$ & 2.44 & 0.365 & {$[102]$} \\
\hline Electroless deposition & $\mathrm{Pt}$ & 0.34 & 0.4 & {$[103]$} \\
\hline Atomic layer deposition & & $\begin{array}{l}1.27 \\
1.27\end{array}$ & $\begin{array}{l}0.254 \\
0.864\end{array}$ & {$[90,91]$} \\
\hline Pt alloy-De alloy & $\mathrm{Pt}-\mathrm{Ni}$ & 8.76 & 1.09 & {$[4]$} \\
\hline
\end{tabular}




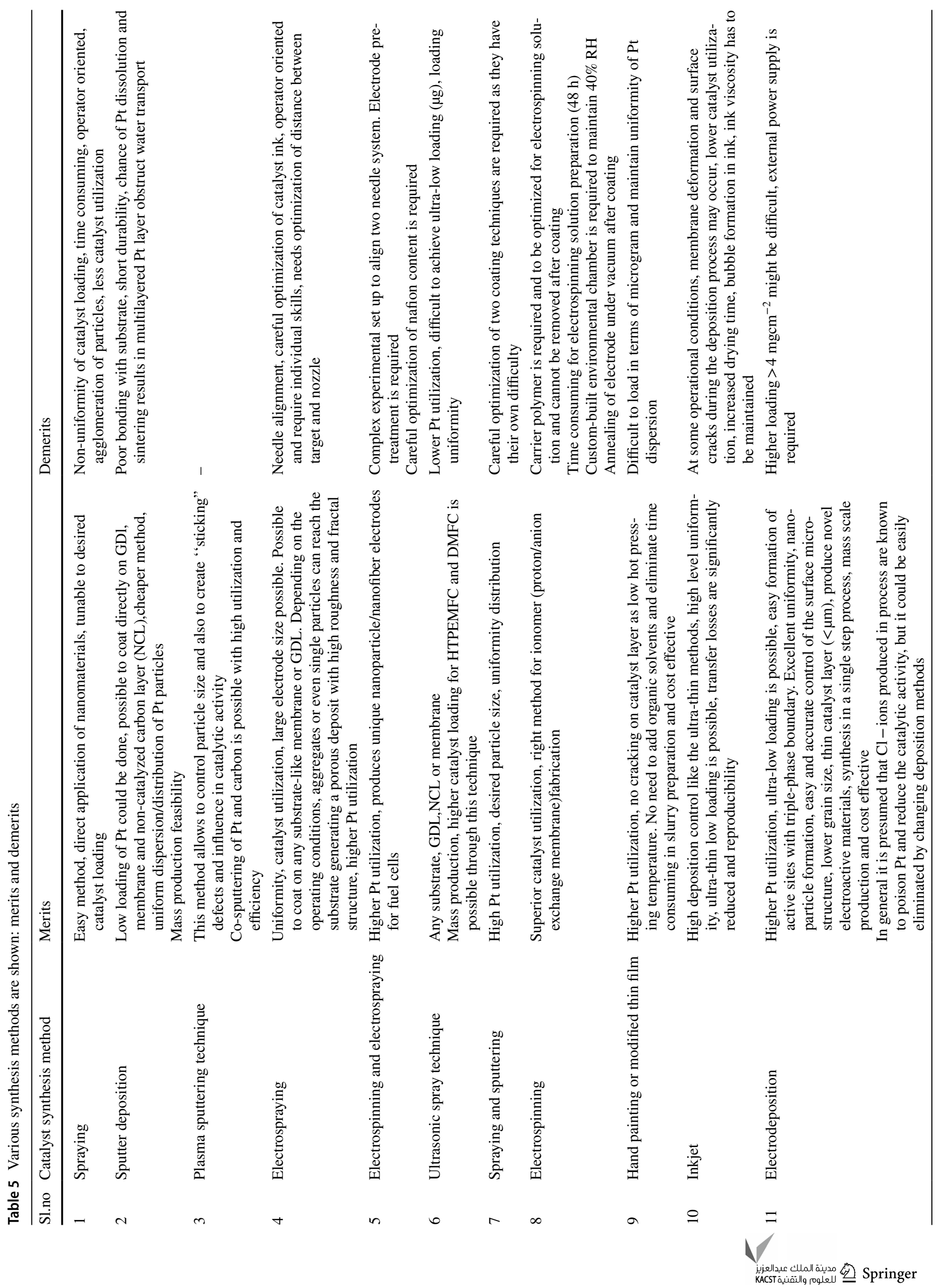




\section{Requirements for PEMFC anode catalyst}

Platinum is a superior catalyst for hydrogen oxidation reaction in the anode of the fuel cell, and it accounts for $50 \%$ of the fuel cell cost [72]. During the stack operation, if flow field in anode side is blocked, the current forces malfunctioning of the cell, and stack. Materials such as carbon, catalyst, water present in the anode layer oxidized to supply the necessary electrons. This is, in turn, leads to high anodic potential $(>1.5 \mathrm{~V})$, and the deterioration of the anode catalyst layer. This implies that the requirement of a novel catalyst layer with strong support material which has electrochemical stability and durability. Nowadays, the catalyst research group must have a strategy to test their catalyst for fuel cell performance and durability at the MEA level. It will further require real-time stack testing and optimizing various parameters by incorporating interdependency of various materials involved in the system.

\section{Maximum mass-specific power density (MSPD)}

DOE has targeted maximum mass-specific power density (MSPD) values [73], which account for both low Pt Anode and low Pt cathode catalysts, as an index for performance with reference to Pt loading. DOE targets more than $5 \mathrm{~mW} \mathrm{\mu g}^{-1}{ }_{\mathrm{Pt} \text { total }}$ at cell voltages higher than $0.65 \mathrm{~V}$ [Department of Energy (DOE)]. This cost reduction to meet DOE target 2020 is possible if we could reduce Pt loading in MEAs to less $125 \mu \mathrm{g} \mathrm{cm}^{-2}$ MEA. In general, it is classified into three regions: (1) $>5 \mathrm{~mW} \mathrm{\mu g}^{-1}$ Pt total (2) between 1 and

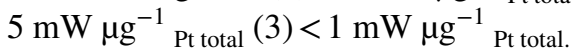

The maximum MSPD value $8.76 \mathrm{~mW} \mathrm{\mu g}^{-1}$ Pt total at $0.65 \mathrm{~V}$ is obtained by a proprietary catalyst, $\mathrm{PtNi} / \mathrm{PtCo}$, of General Motors and United Technologies Research Center (UTRC), and stack modeling performed by ANL [23] (Fig. 3).

\section{Catalyst synthesis and deposition methods: MSPD values}

Various catalyst synthesis methods are listed in Tables 4 and 5 with a primary focus on how an ultra-low loading of catalyst impacts the fuel cell performance by the influence of maximum mass-specific power density (MSPD) values. Each method has achieved maximum performance with low loading of catalyst within the boundary of its limitation.

\section{Combination method of synthesis and coating}

By comparing all synthesis methods (Fig. 4), it is found that the combination method of synthesis and coating (e.g., spraying and sputtering) has achieved increased MSPD values than the specific method of synthesis. It is also encouraged to note that the combination method of synthesis and 


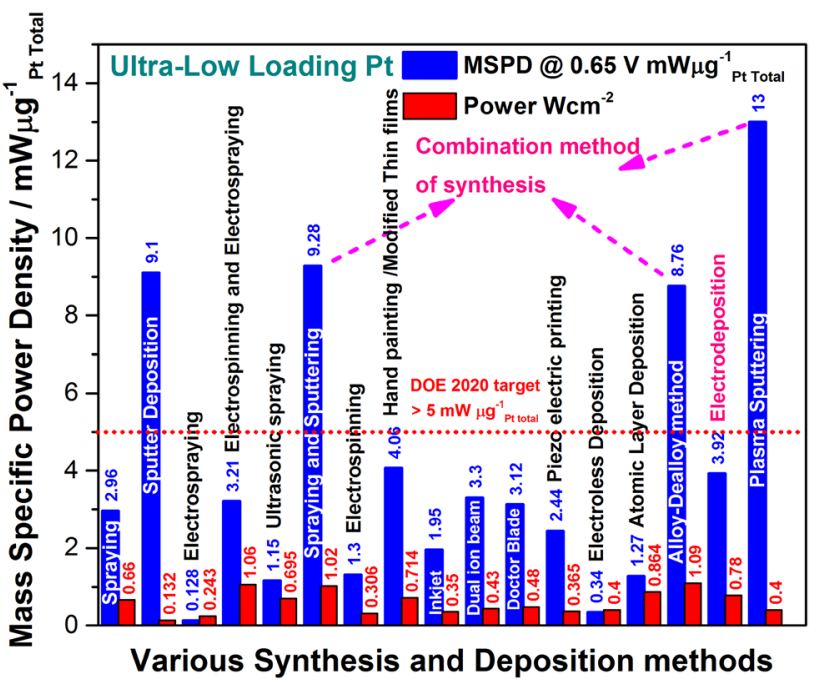

Fig. 4 Ultra-low loading of catalyst (both anode and cathode) by various synthesis methods and MSPD values compared with DOE 2020 target

coating may eliminate the limitation posed by a specific method.

In this review, for example, electrodeposition and plasma sputtering/spraying synthesis methods are recommended for developing an efficient catalyst system which would deliver good performance and stability, at high current density with long-term durability. Here the disadvantages posed by each method are overcome by other methods. Any catalyst synthesis and coating technique, which is being scaled up with high performance/durable catalyst layer, is now a superior priority. Hence, greater attention should be paid not only towards the alloy catalyst but also the catalyst preparation methods, and choice of catalyst support materials [64].

Table 4 shows various catalyst synthesis methods and respective MSPD values along with reference. Table 5 shows various synthesis methods and their merits and demerits.

\section{Conclusion}

Here a brief review of various catalyst synthesis methods and their efficacies is performed with a focus on ultra-low loading of catalyst. Also, the merits and demerits of various synthesis methods are discussed. The ultra-low loading in electrodes was discussed in terms of MSPD values, and is compared with DOE 2020 target values. The catalyst prepared by any combination of the method of synthesis which results in MSPD values more than $5 \mathrm{~mW} \mathrm{\mu g}^{-1} \mathrm{Pt}$ total at $>0.65 \mathrm{~V}$ will be the best catalyst to meet the target of DOE 2020.
Open Access This article is distributed under the terms of the Creative Commons Attribution 4.0 International License (http://creativeco mmons.org/licenses/by/4.0/), which permits unrestricted use, distribution, and reproduction in any medium, provided you give appropriate credit to the original author(s) and the source, provide a link to the Creative Commons license, and indicate if changes were made.

\section{References}

1. Lokurlu, A., Grube, T., Höhlein, B., Stolten, D.: Fuel cells for mobile and stationary applications-cost analysis for combined heat and power stations on the basis of fuel cells. Int. J. Hydrog. Energy 28, 703-711 (2003). https://doi.org/10.1016/S0360 $-3199(02) 00242-2$

2. Ganesan, A., Narayanasamy, M., Shunmugavel, K., Jayanthi Chinnappa, I.: Ultra low loading of anode catalyst for direct methanol fuel cells with $\mathrm{ZrO}_{2}$ /pyrolysed (PANI-melamine) as catalyst support. Int. J. Hydrog. Energy 41, 8963-8977 (2016). https://doi.org/10.1016/J.IJHYDENE.2016.03.135

3. Fuel cell use in the logistics industry $>\mathrm{H} 2$-international, https:// www.h2-international.com/2018/03/06/fuel-cell-use-in-the-logis tics-industry/

4. Thompson, S.T., James, B.D., Huya-Kouadio, J.M., Houchins, C., DeSantis, D.A., Ahluwalia, R., Wilson, A.R., Kleen, G., Papageorgopoulos, D.: Direct hydrogen fuel cell electric vehicle cost analysis: system and high-volume manufacturing description, validation, and outlook. J. Power Sources 399, 304-313 (2018). https://doi.org/10.1016/j.jpowsour.2018.07.100

5. Hydrogen Storage Tech Team Roadmap H2 Storage TT Roadmap. (2017)

6. Kongkanand, A., Mathias, M.F.: The priority and challenge of high-power performance of low-platinum proton-exchange membrane fuel cells. J. Phys. Chem. Lett. 7, 1127-1137 (2016). https://doi.org/10.1021/acs.jpclett.6b00216

7. Götz, M., Wendt, H.: Binary and ternary anode catalyst formulations including the elements W, Sn and Mo for PEMFCs operated on methanol or reformate gas. Electrochim. Acta 43, 3637-3644 (1998). https://doi.org/10.1016/S0013 $-4686(98) 00121-2$

8. He, C., Kunz, H.R., Fenton, J.M.: Electro-oxidation of hydrogen with carbon monoxide on $\mathrm{Pt} / \mathrm{Ru}$-based ternary catalysts. J. Electrochem. Soc. 150, A1017 (2003). https://doi. org/10.1149/1.1583714

9. Venkataraman, R., Kunz, H.R., Fenton, J.M.: Development of new CO tolerant ternary anode catalysts for proton exchange membrane fuel cells. J. Electrochem. Soc. 150, A278 (2003). https://doi.org/10.1149/1.1543567

10. Wang, Y., Chen, K.S., Mishler, J., Cho, S.C., Adroher, X.C.: A review of polymer electrolyte membrane fuel cells: technology, applications, and needs on fundamental research. Appl. Energy 88, 981-1007 (2011). https://doi.org/10.1016/J.APENE RGY.2010.09.030

11. Kim, J.H., Fang, B., Kim, M., Yu, J.-S.: Hollow spherical carbon with mesoporous shell as a superb anode catalyst support in proton exchange membrane fuel cell. Catal. Today 146, 25-30 (2009). https://doi.org/10.1016/J.CATTOD.2009.02.013

12. Yoo, E., Okada, T., Akita, T., Kohyama, M., Honma, I., Nakamura, J.: Sub-nano-Pt cluster supported on graphene nanosheets for $\mathrm{CO}$ tolerant catalysts in polymer electrolyte fuel cells. J. Power Sources 196, 110-115 (2011). https://doi. org/10.1016/J.JPOWSOUR.2010.07.024

13. Cavarroc, M., Ennadjaoui, A., Mougenot, M., Brault, P., Escalier, R., Tessier, Y., Durand, J., Roualdès, S., Sauvage, T., Coutanceau, C.: Performance of plasma sputtered fuel cell

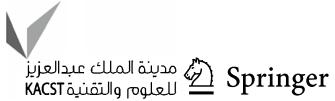


electrodes with ultra-low Pt loadings. Electrochem. Commun. 11, 859-861 (2009). https://doi.org/10.1016/j.eleco m.2009.02.012

14. Antunes, R.A., de Oliveira, M.C.L., Ett, G., Ett, V.: Carbon materials in composite bipolar plates for polymer electrolyte membrane fuel cells: a review of the main challenges to improve electrical performance. J. Power Sources 196, 2945-2961 (2011). https://doi.org/10.1016/J.JPOWSOUR.2010.12.041

15. Liao, M.J., Wei, Z.D., Chen, S.G., Li, L., Ji, M.B., Wang, Y.Q.: Ultra low Pt-loading electrode prepared by displacement of electrodeposited $\mathrm{Cu}$ particles on a porous carbon electrode. Int. J. Hydrog. Energy 35, 8071-8079 (2010). https://doi.org/10.1016/J. IJHYDENE. 2010.01.077

16. Li, W., Chen, Z., Xu, L., Yan, Y.: A solution-phase synthesis method to highly active $\mathrm{Pt}-\mathrm{Co} / \mathrm{C}$ electrocatalysts for proton exchange membrane fuel cell. J. Power Sources 195, 2534-2540 (2010). https://doi.org/10.1016/J.JPOWSOUR.2009.11.035

17. Mukerjee, S., Srinivasan, S.: Enhanced electrocatalysis of oxygen reduction on platinum alloys in proton exchange membrane fuel cells. J. Electroanal. Chem. 357, 201-224 (1993). https://doi. org/10.1016/0022-0728(93)80380-Z

18. Paulus, U.A., Wokaun, A., Scherer, G.G., Schmidt, T.J., Stamenkovic, V., Radmilovic, V., Markovic, N.M., Ross, P.N.: Oxygen reduction on carbon-supported $\mathrm{Pt}-\mathrm{Ni}$ and $\mathrm{Pt}-\mathrm{Co}$ alloy catalysts. J. Phys. Chem. B (2002). https://doi.org/10.1021/jp0134421

19. Di Noto, V., Negro, E.: A new Pt-Rh carbon nitride electrocatalyst for the oxygen reduction reaction in polymer electrolyte membrane fuel cells: synthesis, characterization and single-cell performance. J. Power Sources 195, 638-648 (2010). https://doi. org/10.1016/J.JPOWSOUR.2009.08.005

20. Fiçıcılar, B., Bayrakçeken, A., Eroğlu, İ.: Effect of Pd loading in Pd-Pt bimetallic catalysts doped into hollow core mesoporous shell carbon on performance of proton exchange membrane fuel cells. J. Power Sources 193, 17-23 (2009). https://doi. org/10.1016/J.JPOWSOUR.2009.01.094

21. Thanasilp, S., Hunsom, M.: Effect of Pt: pd atomic ratio in Pt$\mathrm{Pd} / \mathrm{C}$ electrocatalyst-coated membrane on the electrocatalytic activity of ORR in PEM fuel cells. Renew. Energy. 36, 17951801 (2011). https://doi.org/10.1016/J.RENENE.2010.10.024

22. Dubau, L., Durst, J., Maillard, F., Guétaz, L., Chatenet, M., André, J., Rossinot, E.: Further insights into the durability of $\mathrm{Pt} 3 \mathrm{Co} / \mathrm{C}$ electrocatalysts: formation of "hollow" Pt nanoparticles induced by the Kirkendall effect. Electrochim. Acta 56, 10658-10667 (2011). https://doi.org/10.1016/J.ELECT ACTA.2011.03.073

23. Ogawa, S., Babu, S.K., Chung, H.T., Zelenay, P., Padgett, E., Muller, D.A., Kongkanand, A., Litster, S.: Microstructural modeling of PEFC catalyst layer performance and durability. Meet. Abstr. 2, 1374 (2017)

24. Zhang, H., Jin, M., Wang, J., Li, W., Camargo, P.H.C., Kim, M.J., Yang, D., Xie, Z., Xia, Y.: Synthesis of Pd-Pt bimetallic nanocrystals with a concave structure through a bromideinduced galvanic replacement reaction. J. Am. Chem. Soc. 133, 6078-6089 (2011). https://doi.org/10.1021/ja201156s

25. Xia, B.Y., Ng, W.T., Bin, W.H., Wang, X., Lou, X.W.D.: Selfsupported interconnected Pt nanoassemblies as highly stable electrocatalysts for low-temperature fuel cells. Angew. Chemie Int. Ed. 51, 7213-7216 (2012). https://doi.org/10.1002/ anie. 201201553

26. Cui, C.-H., Li, H.-H., Yu, J.-W., Gao, M.-R., Yu, S.-H.: Ternary heterostructured nanoparticle tubes: a dual catalyst and its synergistic enhancement effects for $\mathrm{O} 2 / \mathrm{H} 2 \mathrm{O} 2$ reduction. Angew. Chemie Int. Ed. 49, 9149-9152 (2010). https://doi.org/10.1002/ anie. 201003261
27. Cavaliere, : Electrospinning: designed architectures for energy conversion and storage devices. Energy Environ. Sci. 4, 4761 (2011). https://doi.org/10.1039/c1ee02201f

28. Xiao, X., Liu, X., Zhao, H., Chen, D., Liu, F., Xiang, J., Hu, Z., Li, Y.: Facile shape control of $\mathrm{Co}_{3} \mathrm{O}_{4}$ and the effect of the crystal plane on electrochemical performance. Adv. Mater. 24, 5762-5766 (2012). https://doi.org/10.1002/adma.201202271

29. Aristatil, G., Karthikeya, S., Mani, N., Ingersoll, J.C.: Direct electrodeposition of graphene and platinum based alloys-analysis by SEM/EDX. Asian J. Sci. Res. 8, 245-263 (2015). https://doi. org/10.3923/ajsr.2015.245.263

30. Li, G.-R.: Electrochemical synthesis of nanostructured materials for electrochemical energy conversion and storage. Nanoscale. 5, 4056 (2013). https://doi.org/10.1039/c3nr00607g

31. Vielstich, W., Lamm, A., Gasteiger, H.A., Hubert, A., Yokokawa, H.: Handbook of fuel cells : fundamentals, technology, and applications. Wiley, Chichester (2003)

32. Gencoglu, M.T., Ural, Z.: Design of a PEM fuel cell system for residential application. Int. J. Hydrog. Energy 34, 5242-5248 (2009). https://doi.org/10.1016/j.ijhydene.2008.09.038

33. Scofield, M.E.: A concise guide to sustainable PEMFCs: recent advances in improving both oxygen reduction catalysts and proton exchange membranes. Chem. Soc. Rev. 44, 5836-5860 (2015). https://doi.org/10.1039/C5CS00302D

34. Cao, M., Wu, D., Cao, R.: Recent advances in the stabilization of platinum electrocatalysts for fuel-cell reactions. ChemCatChem. 6, 26-45 (2014). https://doi.org/10.1002/cctc.20130 0647

35. Reetz, M.T., Schulenburg, H., Lopez, M., Spliethoff, B., Tesche, B.: Platinum-nanoparticles on different types of carbon supports: correlation of electrocatalytic activity with carrier morphology

36. Liu, H., Song, C., Zhang, L., Zhang, J., Wang, H., Wilkinson, D.P.: A review of anode catalysis in the direct methanol fuel cell. J. Power Sources 155, 95-110 (2006). https://doi.org/10.1016/j. jpowsour.2006.01.030

37. Bronstein, L.M.: Nanoparticles made in mesoporous solids. Presented at the (2003)

38. Zhang, Y., Erkey, C.: Preparation of supported metallic nanoparticles using supercritical fluids: a review. J. Supercrit. Fluids 38, 252-267 (2006). https://doi.org/10.1016/j.supflu.2006.03.021

39. Lin, J.F., Mason, C.W., Adame, A., Liu, X., Peng, X.H., Kannan, A.M.: Synthesis of Pt nanocatalyst with micelle-encapsulated multi-walled carbon nanotubes as support for proton exchange membrane fuel cells. Electrochim. Acta 55, 6496-6500 (2010). https://doi.org/10.1016/j.electacta.2010.06.032

40. Harish, S., Baranton, S., Coutanceau, C., Joseph, J.: Microwave assisted polyol method for the preparation of $\mathrm{Pt} / \mathrm{C}, \mathrm{Ru} / \mathrm{C}$ and $\mathrm{PtRu} / \mathrm{C}$ nanoparticles and its application in electrooxidation of methanol. J. Power Sources 214, 33-39 (2012). https://doi. org/10.1016/j.jpowsour.2012.04.045

41. Fievet, F., Lagier, J., Blin, B., Beaudoin, B., Figlarz, M.: Homogeneous and heterogeneous nucleations in the polyol process for the preparation of micron and submicron size metal particles. Solid State Ionics 32-33, 198-205 (1989). https://doi. org/10.1016/0167-2738(89)90222-1

42. Leela Mohana Reddy, A., Estaline Amitha, F., Jafri, I., Ramaprabhu, S.: Asymmetric flexible supercapacitor stack. Nanoscale Res. Lett. 3, 145-151 (2008). https://doi.org/10.1007/ s11671-008-9127-3

43. Kaempgen, M., Chan, C.K., Ma, J., Cui, Y., Gruner, G.: Printable thin film supercapacitors using single-walled carbon nanotubes. Nano Lett. 9, 1872-1876 (2009). https://doi.org/10.1021/n1803 8579

44. Cheng, N., Shao, Y., Liu, J., Sun, X.: Electrocatalysts by atomic layer deposition for fuel cell applications. Nano Energy. (2016). https://doi.org/10.1016/j.nanoen.2016.01.016 
45. Sammes, N.: Fuel cell technology. Springer, London (2006)

46. Blomen, L.J.M.J., Mugerwa, M.N.: Fuel cell systems. Plenum Press, Berlin (1993)

47. Mench, M.M.: Fuel cell engines. John Wiley \& Sons, Hoboken (2008)

48. Gavin, D., Harper, J.: Fuel cell projects for the evil genius. McGraw-Hill companies Inc., New York (2008)

49. Supramaniam, S.: Fuel cells: from fundamentals to applications: Supramaniam Srinivasan: 9780387251165: Amazon.com: Books. Springer, NY USA (2006)

50. Hermann, A., Chaudhuri, T., Spagnol, P.: Bipolar plates for PEM fuel cells: a review. Int. J. Hydrog. Energy 30, 1297-1302 (2005). https://doi.org/10.1016/j.ijhydene.2005.04.016

51. Debe, M.K.: Electrocatalyst approaches and challenges for automotive fuel cells. Nature 486, 43-51 (2012). https://doi. org/10.1038/nature11115

52. Zhang, Z:: An overview of metal oxide materials as electrocatalysts and supports for polymer electrolyte fuel cells. Energy Environ. Sci. 7, 2535 (2014). https://doi.org/10.1039/C3EE43886D

53. Tripković, V., Abild-Pedersen, F., Studt, F., Cerri, I., Nagami, T., Bligaard, T., Rossmeisl, J.: Metal oxide-supported platinum overlayers as proton-exchange membrane Fuel Cell cathodes. ChemCatChem. 4, 228-235 (2012). https://doi.org/10.1002/ cetc. 201100308

54. Liu, Z., Lin, X., Lee, J.Y., Zhang, W., Han, M., Gan, L.M.: Preparation and characterization of platinum-based electrocatalysts on multiwalled carbon nanotubes for proton exchange membrane fuel cells. Langmuir 18, 4054-4060 (2002). https://doi. org/10.1021/la0116903

55. Wang, C., Waje, M., Wang, X., Tang, J.M., Haddon, R.C., Yan, Y.: Proton exchange membrane fuel cells with carbon nanotube based electrodes. Nano Lett. 4, 345-348 (2004). https://doi. org/10.1021/n1034952p

56. Wang, C.-H., Du, H.-Y., Tsai, Y.-T., Chen, C.-P., Huang, C.-J., Chen, L.C., Chen, K.H., Shih, H.-C.: High performance of low electrocatalysts loading on CNT directly grown on carbon cloth for DMFC. J. Power Sources 171, 55-62 (2007). https://doi. org/10.1016/j.jpowsour.2006.12.028

57. Hsin, Y.L., Hwang, K.C., Yeh, C.-T.: Poly(vinylpyrrolidone)modified graphite carbon nanofibers as promising supports for PtRu catalysts in direct methanol fuel cells. J. Am. Chem. Soc. 129, 9999-10010 (2007). https://doi.org/10.1021/ja072367a

58. Maiyalagan, T.: Pt-Ru nanoparticles supported PAMAM dendrimer functionalized carbon nanofiber composite catalysts and their application to methanol oxidation. J. Solid State Electrochem. 13, 1561-1566 (2009). https://doi.org/10.1007/s1000 8-008-0730-0

59. Song, S., Liang, Y., Li, Z., Wang, Y., Fu, R., Wu, D., Tsiakaras, P.: Effect of pore morphology of mesoporous carbons on the electrocatalytic activity of Pt nanoparticles for fuel cell reactions. Appl. Catal. B Environ. 98, 132-137 (2010). https://doi. org/10.1016/j.apcatb.2010.05.021

60. Honda, K., Yoshimura, M., Rao, T.N., Tryk, D., Fujishima, A., Yasui, K., Sakamoto, Y., Nishio, K., Masuda, H.: Electrochemical properties of Pt-modified nano-honeycomb diamond electrodes. J. Electroanal. Chem. 514, 35-50 (2001). https://doi. org/10.1016/S0022-0728(01)00614-3

61. Montilla, F., Morallón, E., Duo, I., Comninellis, C., Vázquez, J.: Platinum particles deposited on synthetic boron-doped diamond surfaces, application to methanol oxidation. Electrochim. Acta. 48, 3891-3897 (2003). https://doi.org/10.1016/S0013 -4686(03)00526-7

62. Antolini, E., Gonzalez, E.R.: Ceramic materials as supports for low-temperature fuel cell catalysts. Solid State Ionics 180, 746-763 (2009). https://doi.org/10.1016/j.ssi.2009.03.007
63. Samad, S., Loh, K.S., Wong, W.Y., Lee, T.K., Sunarso, J., Chong, S.T., Wan Daud, W.R.: Carbon and non-carbon support materials for platinum-based catalysts in fuel cells. Int. J. Hydrog. Energy 43, 7823-7854 (2018). https://doi.org/10.1016/J.IJHYD ENE.2018.02.154

64. Ganesan, A., Narayanasamy, M., Shunmugavel, K.: Self-humidifying manganese oxide-supported Pt electrocatalysts for highlydurable PEM fuel cells. Electrochim. Acta 285, 47-59 (2018). https://doi.org/10.1016/j.electacta.2018.08.001

65. Debe, M.K., Atanasoski, R.T., Steinbach, A.J.: Nanostructured thin film electrocatalysts - current status and future potential. In: ECS transactions. pp. 937-954. The Electrochemical Society (2011)

66. Debe, M.K.: Advanced cathode catalysts and supports for PEM fuel cells 2011 annual merit review DOE hydrogen and fuel cells and vehicle technologies programs (2011)

67. van der Vliet, D., Wang, C., Debe, M., Atanasoski, R., Markovic, N.M., Stamenkovic, V.R.: Platinum-alloy nanostructured thin film catalysts for the oxygen reduction reaction. Electrochim. Acta 56, 8695-8699 (2011). https://doi.org/10.1016/J. ELECTACTA.2011.07.063

68. Debe, M.K., Schmoeckel, A.K., Vernstrom, G.D., Atanasoski, R.: High voltage stability of nanostructured thin film catalysts for PEM fuel cells. J. Power Sources 161, 1002-1011 (2006). https://doi.org/10.1016/J.JPOWSOUR.2006.05.033

69. Debe, M.K., Steinbach, A.J., Noda, K.: Stop-start and highcurrent durability testing of nanostructured thin film catalysts for PEM fuel cells. In: ECS Trans. pp. 835-853. ECS (2006)

70. Debe, M.K.: Nanostructured thin film electrocatalysts for PEM fuel cells-a tutorial on the fundamental characteristics and practical properties of NSTF catalysts. ECS Trans. 45, 47-68 (2012). https://doi.org/10.1149/1.3701968

71. Sasaki, K., Naohara, H., Cai, Y., Choi, Y.M., Liu, P., Vukmirovic, M.B., Wang, J.X., Adzic, R.R.: Core-protected platinum monolayer shell high-stability electrocatalysts for fuel-cell cathodes. Angew. Chemie Int. Ed. 49, 8602-8607 (2010). https ://doi.org/10.1002/anie.201004287

72. Banham, D., Ye, S.: Current status and future development of catalyst materials and catalyst layers for proton exchange membrane fuel cells: an industrial perspective. ACS Energy Lett. 2, 629-638 (2017). https://doi.org/10.1021/acsenergyl ett.6b00644

73. Brouzgou, A., Song, S.Q., Tsiakaras, P.: Low and non-platinum electrocatalysts for PEMFCs: current status, challenges and prospects. Appl. Catal. B Environ. 127, 371-388 (2012). https://doi. org/10.1016/j.apcatb.2012.08.031

74. Cooper, C.D., Burk, J.J., Taylor, C.P., Buratto, S.K.: Ultra-low Pt loading catalyst layers prepared by pulse electrochemical deposition for PEM fuel cells. J. Appl. Electrochem. 47, 699-709 (2017). https://doi.org/10.1007/s10800-017-1071-4

75. Gruber, D., Ponath, N., Müller, J., Lindstaedt, F.: Sputter-deposited ultra-low catalyst loadings for PEM fuel cells. J. Power Sources 150, 67-72 (2005). https://doi.org/10.1016/J.JPOWS OUR.2005.02.076

76. Saha, M.S., Gullá, A.F., Allen, R.J., Mukerjee, S.: High performance polymer electrolyte fuel cells with ultra-low Pt loading electrodes prepared by dual ion-beam assisted deposition. Electrochim. Acta 51, 4680-4692 (2006). https://doi.org/10.1016/j. electacta.2006.01.006

77. Xiong, L., Manthiram, A.: High performance membrane-electrode assemblies with ultra-low Pt loading for proton exchange membrane fuel cells. Electrochim. Acta 50, 3200-3204 (2005). https://doi.org/10.1016/j.electacta.2004.11.049

78. Huang, T.W., Qayyum, H., Lin, G.R., Chen, S.Y., Tseng, C.J.: Production of high-performance and improved-durability Ptcatalyst/support for proton-exchange-membrane fuel cells with

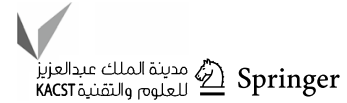


pulsed laser deposition. J. Phys. D Appl. Phys. 49, 255601 (2016). https://doi.org/10.1088/0022-3727/49/25/255601

79. Brault, P., Caillard, A., Thomann, A.L., Mathias, J., Charles, C., Boswell, R.W., Escribano, S., Durand, J., Sauvage, T.: Plasma sputtering deposition of platinum into porous fuel cell electrodes. J. Phys. D Appl. Phys. 37, 3419-3423 (2004). https:// doi.org/10.1088/0022-3727/37/24/010

80. Shukla, S.: Experimental analysis of inkjet printed polymer electrolyte fuel cell electrodes. (2016)

81. Yu, H., Baricci, A., Roller, J., Wang, Y., Casalegno, A., Mustain, W.E., Maric, R.: Ultra-low Pt loading catalyst layers for PEMFC using reactive spray deposition technology. ECS Trans. 69, 487-496 (2015). https://doi.org/10.1149/06917 .0487 ecst

82. Billy, E., Maillard, F., Morin, A., Guetaz, L., Emieux, F., Thurier, C., Doppelt, P., Donet, S., Mailley, S.: Impact of ultra-low $\mathrm{Pt}$ loadings on the performance of anode/cathode in a protonexchange membrane fuel cell. J. Power Sources 195, 2737-2746 (2010). https://doi.org/10.1016/j.jpowsour.2009.10.101

83. Yazici, M.S., Azder, M.A., Salihoglu, O., Boyaci San, F.G.: Ultralow Pt loading on CVD graphene for acid electrolytes and PEM fuel cells. Int. J. Hydrog. Energy. 6-11 (2018). https://doi. org/10.1016/j.ijhydene.2018.06.020

84. Wang, X., Richey, F.W., Wujcik, K.H., Elabd, Y.A.: ultra-low platinum loadings in polymer electrolyte membrane fuel cell electrodes fabricated via simultaneous electrospinning/electrospraying method. J. Power Sources 264, 42-48 (2014). https:// doi.org/10.1016/J.JPOWSOUR.2014.04.052

85. Breitwieser, M., Klingele, M., Britton, B., Holdcroft, S., Zengerle, R., Thiele, S.: Improved Pt-utilization efficiency of low Pt-loading PEM fuel cell electrodes using direct membrane deposition. Electrochem. Commun. 60, 168-171 (2015). https:// doi.org/10.1016/j.elecom.2015.09.006

86. Su, H.N., Zeng, Q., Liao, S.J., Wu, Y.N.: High performance membrane electrode assembly with ultra-low platinum loading prepared by a novel multi catalyst layer technique. Int. J. Hydrogen Energy 35, 10430-10436 (2010). https://doi.org/10.1016/j. ijhydene.2010.06.070

87. Tian, Z.Q., Lim, S.H., Poh, C.K., Tang, Z., Xia, Z., Luo, Z., Shen, P.K., Chua, D., Feng, Y.P., Shen, Z., Lin, J.: A highly order-structured membrane electrode assembly with vertically aligned carbon nanotubes for ultra-low Pt loading PEM fuel cells. Adv. Energy Mater. 1, 1205-1214 (2011). https://doi. org/10.1002/aenm.201100371

88. Brodt, M., Wycisk, R., Pintauro, P.N.: Nanofiber electrodes with low platinum loading for high power hydrogen/air PEM fuel cells. J. Electrochem. Soc. 160, F744-F749 (2013). https:// doi.org/10.1149/2.008308jes

89. Dang, D., Zou, H., Xiong, Z., Hou, S., Shu, T., Nan, H., Zeng, X., Zeng, J., Liao, S.: High-performance, ultralow platinum membrane electrode assembly fabricated by in situ deposition of a Pt shell layer on carbon-supported pd nanoparticles in the catalyst layer using a facile pulse electrodeposition approach. ACS Catal. 5, 4318-4324 (2015). https://doi.org/10.1021/acscatal.5b00030

90. Hsieh, C.-T., Liu, Y.-Y., Tzou, D.-Y., Chen, W.-Y.: Atomic layer deposition of platinum nanocatalysts onto three-dimensional carbon nanotube/graphene hybrid. J. Phys. Chem. C 116, 2673526743 (2012). https://doi.org/10.1021/jp303552j

91. Shu, T., Dang, D., Xu, D., Chen, R., Liao, S., Hsieh, C., Su, A., Song, H., Du, L.: High-performance MEA prepared by direct deposition of platinum on the gas diffusion layer using an atomic layer deposition technique. Electrochim. Acta 177, 168-173 (2015). https://doi.org/10.1016/J.ELECTACTA.2015.03.031

92. Zeis, R., Mathur, A., Fritz, G., Lee, J., Erlebacher, J.: Platinumplated nanoporous gold: an efficient, low Pt loading electrocatalyst for PEM fuel cells. J. Power Sources 165, 65-72 (2007). https://doi.org/10.1016/j.jpowsour.2006.12.007

93. Ohayre, R., Lee, S.J., Cha, S.W., Prinz, F.B.: A sharp peak in the performance of sputtered platinum fuel cells at ultra-low platinum loading. J. Power Sources. 109, 483-493 (2002). https://doi. org/10.1016/s0378-7753(02)00238-0

94. Chen, S., Wei, Z., Li, H., Li, L.: High Pt utilization PEMFC electrode obtained by alternative ion-exchange/electrodeposition. Chem. Commun. 46, 8782-8784 (2010). https://doi.org/10.1039/ c0cc02802a

95. Mougenot, M., Caillard, A., Brault, P., Baranton, S., Coutanceau, C.: High performance plasma sputtered PdPt fuel cell electrodes with ultra low loading. Int. J. Hydrog. Energy 36, 8429-8434 (2011). https://doi.org/10.1016/j.ijhydene.2011.04.080

96. Martin, S., Garcia-Ybarra, P.L., Castillo, J.L.: High platinum utilization in ultra-low Pt loaded PEM fuel cell cathodes prepared by electrospraying. Int. J. Hydrog. Energy 35, 10446-10451 (2010). https://doi.org/10.1016/j.ijhydene.2010.07.069

97. Martin, S., Garcia-Ybarra, P.L., Castillo, J.L.: Electrospray deposition of catalyst layers with ultra-low Pt loadings for PEM fuel cells cathodes. J. Power Sources 195, 2443-2449 (2010). https ://doi.org/10.1016/j.jpowsour.2009.11.092

98. Millington, B., Whipple, V., Pollet, B.G.: A novel method for preparing proton exchange membrane fuel cell electrodes by the ultrasonic-spray technique. J. Power Sources 196, 8500-8508 (2011). https://doi.org/10.1016/J.JPOWSOUR.2011.06.024

99. Ganesan, A., Narayanasamy, M., Shunmugavel, K., Jayanthi Chinnappa, I., Aristatil Ganesan, Mani Narayanasamy, Karthikeyan Shunmugavel, I.J.C.: Ultra low loading of anode catalyst for direct methanol fuel cells with $\mathrm{ZrO}<$ inf $>2</$ inf $>$ / pyrolysed (PANI-melamine) as catalyst support. Int. J. Hydrog. Energy. 41, 8963-8977 (2016). https://doi.org/10.1016/j.ijhyd ene.2016.03.135

100. Ramaswamy, N., Arruda, T.M., Wen, W., Hakim, N., Saha, M., Gullá, A., Mukerjee, S.: Enhanced activity and interfacial durability study of ultra low Pt based electrocatalysts prepared by ion beam assisted deposition (IBAD) method. Electrochim. Acta 54, 6756-6766 (2009). https://doi.org/10.1016/j.elect acta.2009.06.040

101. Park, I.S., Li, W., Manthiram, A.: Fabrication of catalyst-coated membrane-electrode assemblies by doctor blade method and their performance in fuel cells. J. Power Sources 195, 7078-7082 (2010). https://doi.org/10.1016/j.jpowsour.2010.05.004

102. Saha, M.S., Malevich, D., Halliop, E., Pharoah, J.G., Peppley, B.A., Karan, K.: Electrochemical activity and catalyst utilization of low Pt and thickness controlled membrane electrode assemblies. J. Electrochem. Soc. 158, B562 (2011). https://doi. org/10.1149/1.3559188

103. Rajalakshmi, N., Ryu, H., Shaijumon, M.M., Ramaprabhu, S.: Performance of polymer electrolyte membrane fuel cells with carbon nanotubes as oxygen reduction catalyst support material. J. Power Sources 140, 250-257 (2005). https://doi.org/10.1016/J. JPOWSOUR.2004.08.042

Publisher's Note Springer Nature remains neutral with regard to jurisdictional claims in published maps and institutional affiliations. 